\title{
生体内酸化還元物質を高感度かつ選択的に検出する蛍光プローブの開発と応用
}

\author{
松 岡悠太
}

\section{Developments of Profluorescent Nitroxide Probes for Highly Sensitive and Selective Detection of Biological Redox Molecules}

\author{
Yuta Matsuoka \\ Physical Chemistry for Life Science Laboratory, Faculty of Pharmaceutical Sciences, \\ Kyushu University; 3-1-1 Maidashi, Higashi-ku, Fukuoka 812-8582, Japan.
}

(Received July 2, 2021)

\begin{abstract}
Disruption of the redox balance in vivo is closely involved in the development of various diseases associated with oxidative stress. Therefore, methods for the in vivo analysis of antioxidants and free radicals are essential to elucidate the pathogenic mechanisms of such diseases. Although profluorescent nitroxide probes can be used to evaluate redox molecules with high sensitivity, these probes have low selectivity. Recently, we developed two profluorescent nitroxide probes, 15-( (9- (ethylimino) -10-methyl-9Hbenzo $[a]$ phenoxazin-5-yl) amino) -3,11-dioxa-7-azadispiro-hexadecan-7-yloxyl (NileDiPy) and 2,2,6-trimethyl-4-(4-nitrobenzo [1,2,5] oxadiazol-7-ylamino)-6-pentylpiperidine-1-oxyl (NBD-Pen), which had high sensitivity and selectivity toward ascorbic acid and lipid-derived radicals, respectively. These probes can react sensitively and selectively to each target molecule and can be used in animal experiments. In this paper, we review the design strategies and application of these profluorescent nitroxide probes.
\end{abstract}

Key words_ antioxidant; free radical; ascorbic acid; lipid derived radicals; HPLC; MS

\section{1. はじめに}

われわれの生体内では高い酸化作用を示すフリー ラジカル種と，それらを除去する抗酸化物質が一定 のバランス（レドックスバランス）を保ち, 存在し ている.11)しかしながら，様々な内因性・外因性ス トレスにより, ラジカル種が過剰に発現，若しくは 抗酸化物質が欠乏するとこれらのバランスが崩壊 し, がんや神経変性疾患など, 種々の酸化ストレス

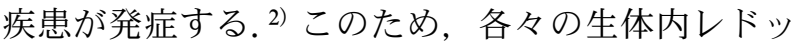
クス分子を精確に評価・分析する技術は，疾患の診 断及び発症機序の解明に大きく貢献する.

抗酸化物質・フリーラジカル種評価法の 1 つに, 蛍光二トロキシドプローブによる評価法がある. ${ }^{3)}$ ニトロキシドは自身の常磁性により, 周囲に存在す る蛍光原子団を消光させる. ${ }^{4)}$ そこで，二トロキシ ドと蛍光原子団を連結させることにより，三トロキ

九州大学大学院薬学研究院生命物理化学分野 (T8128582 福岡市東区馬出 3-1-1)

e-mail: ymatsu@phar.kyushu-u.ac.jp 本総説は, 2020 年度日本薬学会九州山口支部学術奨励 賞の受賞を記念して記述したものである.
シドが測定対象となるレドックス分子と反応し常磁 性を失うことで発光する Turn-On 型蛍光プローブ が設計可能である（Fig. 1)。しかしながら，二ト ロキシドは広範な分子種に対して反応性を示すこと から，プローブが実際に何を捉え蛍光応答を示して いるかが不明確であり，その反応選択性に問題を抱 えていた.

一方，筆者が所属する研究室ではこれまでに，二 トロキシド反応部位近傍への置換基修飾法を確立 し，様々な反応性を有したニトロキシド誘導体を合 成してきた.5) そこで，これらを蛍光発光制御部位 として応用すれば，抗酸化物質・フリーラジカルに 対して高い選択性を有した蛍光プローブの開発が可 能になると考えた。 以上より，本研究では，生体内 レドックス分子であるアスコルビン酸（ascorbic acid; AsA） ${ }^{6}$ 及び脂質由来フリーラジカル種（脂質 ラジカル $)^{7,8)}$ に対する蛍光ニトロキシドプローブの 開発を行った。

2.アスコルビン酸蛍光検出プローブの開発

AsA は水溶性ビタミン C として広く知られてい る小分子化合物であり，抗酸化分子又は補酵素とし 


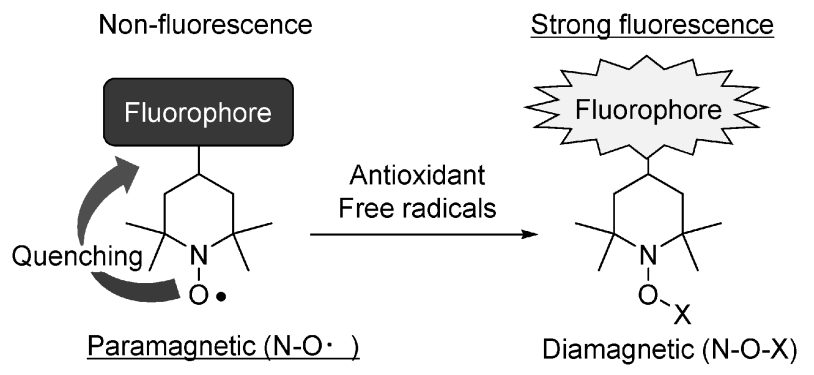

Fig. 1. Detection Principle of Redox Molecules Using Profluorescent Nitroxides

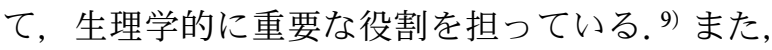
近年では，高濃度の AsA 溶液を静脈内注射する 「高濃度 AsA 点滴療法」を, 既存の抗がん剂や化学 療法と併用することでがん治療効果を向上，さらに 副作用を軽減すること10)が報告されており，既に臨 床応用も進められている。.またこれらの治療法にお いては血中 AsA 濃度を維持・管理する必要があ り，随時その濃度をモニタリング可能な検出手法が 求められる.

従来の AsA 検出手法としては主に HPLC を用い た電気化学的検出手法 (electro-chemical detection; ECD）が応用されてきた. ${ }^{11)}$ 本手法は，極めて高感 度かつ高選択的に AsA を検出可能であるが，それ ぞれの検体を個別にしか測定できないことから，多 数検体の一斉解析には不向きであった。 そのため, 臨床応用を見据えた上では，より迅速かつ高感度な 検出手法の開発が望まれていた。

一方で, 当研究室では近年 1,2,2,6,6-pentamethyl-1-piperidine と種々のケトン誘導体を原料と した新たなニトロキシド 2,6 位置換修飾合成法を確 立した. ${ }^{5)}$ さらに，ニトロキシドの酸化還元電位は ピペリジン環 2,6 位への置換基修飾により大きく変 化し，それらの中でもへテロ原子を含むシクロへキ シル基を有したニトロキシド誘導体では特に高い AsA 反応性がみられた. ${ }^{12)}$ そこで蛍光ニトロキシド プローブ，ニトロキシド部位にこれら AsA 高反応 性ニトロキシド導入することで AsA 高反応性蛍光 ニトロキシドプローブを開発し，臨床応用を見据え た迅速かつ高感度な検出手法を提唱できるのではな いかと考えた。

以上より, AsA 高反応性長波長蛍光ニトロキシ ドプローブとして 15- ( (9- (ethylimino) -10-methyl9Hbenzo $[a]$ phenoxazin-5-yl) amino) -3,11-dioxa-7-

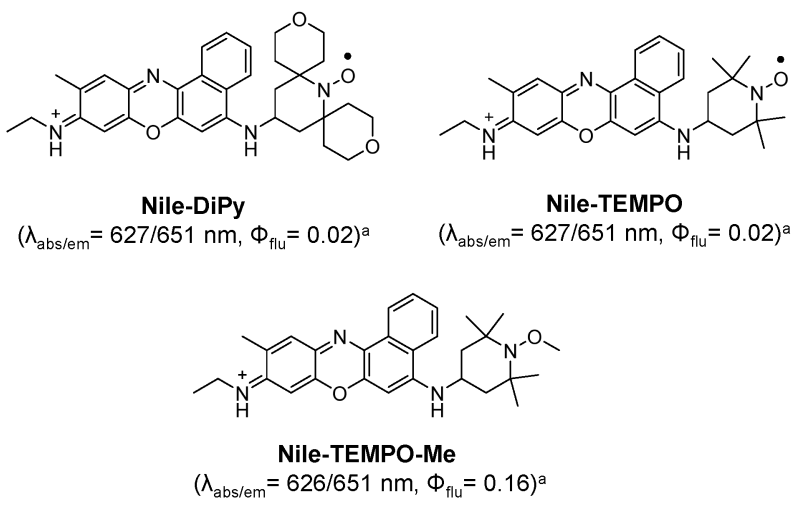

Fig. 2. Chemical Structures and Photochemical Properties of Nile-Blue-based Profluorescent Nitroxides Used in This Study

${ }^{\mathrm{a}}$ Measured in phosphate buffered saline ( $\mathrm{pH}$ 7.4).

azadispiro-hexadecan-7-yloxyl(Nile-DiPy) を合成し た（Fig. 2). 6) 蛍光原子団としては，長波長蛍光原 子団である Nile Blue を用いた。 また参照化合物と して，TEMPO 構造を有した Nile-TEMPO，さら にその N-O ラジカル部位をメチル化し蛍光消光能 を消失させた Nile-TEMPO-Meについても別途合 成した。今回検討したいずれの蛍光化合物も，吸収 蛍光極大波長をそれぞれ $630 \mathrm{~nm}, 650 \mathrm{~nm}$ 付近に有 した．続いて，各分子の蛍光量子収率の測定を行つ たところ，ラジカルを消失させた Nile-TEMPO-Me では PBS 中において高い蛍光発光が観測された $\left(\Phi_{\text {Nile-TEMPO-Me }}=0.16\right)$.これに対して, N-O ラジカ ルを有する Nile-DiPy，Nile-TEMPO では蛍光量子 収率が著しく低下した（ $\Phi_{\text {Nile-DiPy }}=0.02, \Phi_{\text {Nile-TEMPO }}$ $=0.02)$.

\section{Nile-DiPy を用いたアスコルビン酸の高感度} 検出及び応用

続いて，本プローブの AsA に対する反応性を評 価した（Fig. 3)。添加した AsA に対して用量依存 的な蛍光強度の上昇が確認された $[\mathrm{Fig} .3(\mathrm{a})]$ 。続 いて, Nile-DiPy と AsA との反応機構を評価する ため，速度論的同位体効果（kinetic isotope effect; KIE）を検討した．AsA はそのビニル性水酸基が強 い酸性を示すことから，重水中においてはこの反応 部位の水酸基水素原子が重水中の重水素イオンと置 換されることが推測される。そこで本検討では Nile-DiPy と AsA を水中, 重水中において混和さ せ，その際の二次反応速度定数を算出した $[\mathrm{Fig} .3$ (b) ]. Nile-DiPy と AsA の反応速度定数は水中, 
a

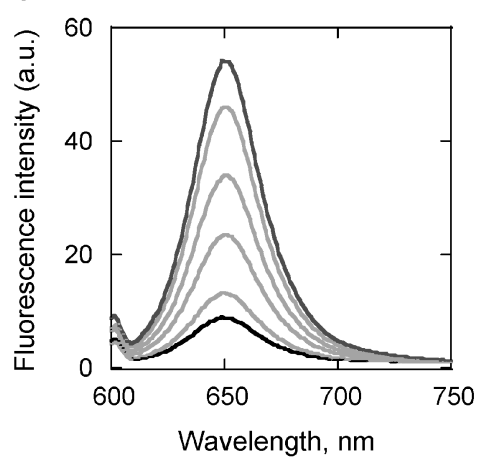

C

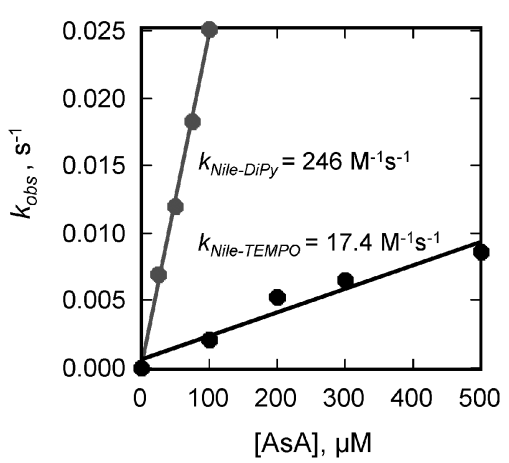

b

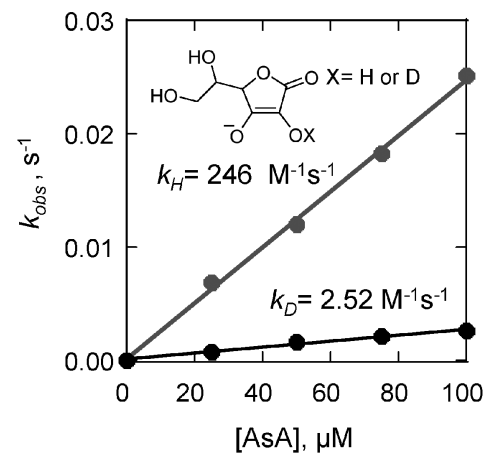

Fig. 3. Reactivities of Nile-DiPy and Nile-TEMPO toward AsA

(a) Emission spectra $\left(\lambda_{\mathrm{ex}}: 600 \mathrm{~nm}\right)$ of $2 \mu \mathrm{M}$ Nile-DiPy in $0.1 \mathrm{M}$ PBS buffer at pH 7.4 after adding $0,0.13,0.25,0.50,2.0,4.0 \mu \mathrm{M}$ (DMSO $1 \%$ solution), (b) plots of $k_{\text {obs }} v s$. [AsA] for the reaction of Nile-DiPy and AA in $\mathrm{H}_{2} \mathrm{O}$ and $\mathrm{D}_{2} \mathrm{O}$, (c) plots of $k_{\mathrm{obs}} v s$. [AsA] for the reaction of Nile-DiPy and Nile-TEMPO to AsA in $\mathrm{H}_{2} \mathrm{O}$. Reprinted with permission from Matsuoka Y., et al. RSC Adv., 6(65), 60907-60915 (2016). Copyright 2016 Royal Society of Chemistry.

重水中においてそれぞれ $k_{\mathrm{H}_{2} \mathrm{O}}=246 \mathrm{M}^{-1} \mathrm{~s}^{-1}, k_{\mathrm{D}_{2} \mathrm{O}}$ $=2.52 \mathrm{M}^{-1} \mathrm{~s}^{-1}$ と求められ, $\operatorname{KIE}\left(k_{\mathrm{H}_{2} \mathrm{O}} / k_{\mathrm{D}_{2} \mathrm{O}}\right)$ は 9.77 であった。本結果より Nile-DiPy と AsA の反 応は hydrogen atom transfer (HAT) により進行す ることが示唆された。さらにNile-TEMPOを用 い，水中での AsA との反応における二次反応速度 定数を算出したところ，その反応速度定数は $k_{\mathrm{H}_{2} \mathrm{O}}$ $=17.4 \mathrm{M}^{-1} \mathrm{~s}^{-1}$ と決定され，Nile-DiPy は NileTEMPO に対してその反応速度定数が約 14 倍大き かった [Fig. 3(c)]．さらにそれぞれの化合物の検 出限界（limit of detection; LOD）を測定したとこ ろ, Nile-DiPy は Nile-TEMPO に比べ，その LOD が約 70 倍向上していることが明らかとなった $\left(\mathrm{LOD}_{\text {Nile-DiPy }}=9.72 \mathrm{nM}, \mathrm{LOD}_{\text {Nile-TEMPO }}=826 \mathrm{nM}\right)$.

Nile-DiPy を様々な生体内還元物質 (AsA, GSH, HPMC, NADH, catechin: $50 \mu \mathrm{M})$ と混和させ, そ の蛍光応答性について経時的に測定した（Fig. 4).

Nile-DiPy はAsA に対しては顕著な蛍光応答性を 示す一方でその他の還元物質を添加した際にはほと んど蛍光上昇を示さなかった. 以上の結果より,

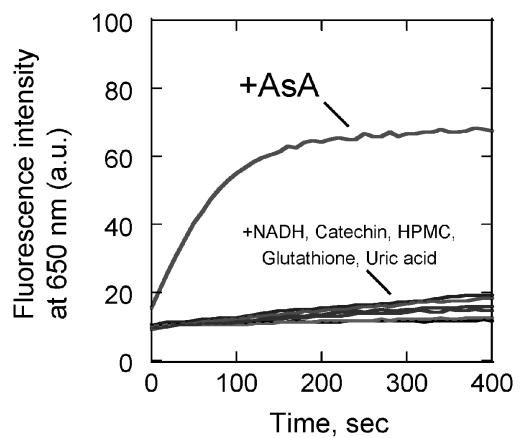

Fig. 4. Response of Nile-DiPy to Various Redox Substances, Time Courses of Emission Intensities at $650 \mathrm{~nm}\left(\lambda_{\mathrm{ex}}: 600 \mathrm{~nm}\right)$ of $2 \mu \mathrm{M}$ Nile-DiPy with $50 \mu \mathrm{M}$ Redox Substances

Reprinted with permission from Matsuoka Y., et al. RSC Adv., 6 (65), 60907-60915 (2016). Copyright 2016 Royal Society of Chemistry.

Nile-DiPy は高感度かつ高選択的に系中の AsAを 検出可能であることが示された。

続いて, Nile-DiPyを用いた AsA 蛍光分析法に より，健常・streptozotocin（STZ）誘発糖尿病モ デルラット血漿中 AsA の定量が可能であるか検討 した（Fig. 5)。STZ はインスリンを産出する膵臓 $\beta$ 細胞に対して高い毒性を示すことで I 型糖尿病を 
a

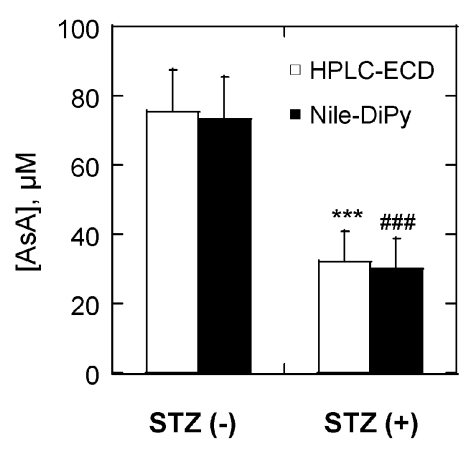

b

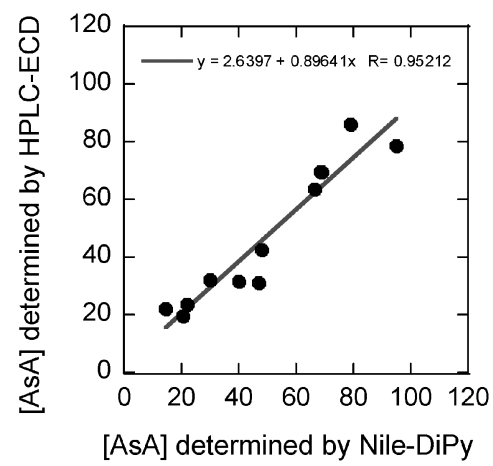

Fig. 5. (a) Measurement of Ascorbic Acid in Plasma of Normal and STZ-induced Diabetic Rats Using Nile-DiPy, and (b) Correlation between AsA Measured by HPLC-ECD and Nile-DiPy

All results are shown as means + S.D. ${ }^{* * *} p<0.001 v s$. STZ $(+)$ group, ${ }^{\sharp \sharp} p<0.001 v s$. STZ $(+)$ group, $n=5-7$. Reprinted with permission from Matsuoka Y., et al. RSC Adv., 6 (65) , 60907-60915 (2016) . Copyright 2016 Royal Society of Chemistry.

引き起こす．さらに糖尿病ラットにおいてその血漿 中 AsA 濃度が，健常ラットに比べ著しく低下す る. ${ }^{13)}$ 本実験では 7 週齢の Wister ラットはコント ロール群 $(n=5)$ と STZ 誘発 I 型糖尿病群 $(n=7)$ に分け，その血漿中 AsA 濃度を Nile-DiPy を用い た蛍光検出法・HPLC-ECD 法，それぞれを用い求 めた。 HPLC-ECD 法により各群ラットの血漿中 AsA を測定したところ，従来の報告通り，健常 ラット群に比べ STZ 誘発糖尿病モデルラット群で は血漿中 AsA が顕著に低下した [Fig. 5 (a) ]。さ らにNile-DiPyを用いた蛍光検出法は従来の HPLC-ECD 法とほぼ同等結果を示した［Fig. 5 (b) ]. 以上の結果より，Nile-DiPy を用いた蛍光分 析法が，従来法と同等にAsA を定量可能であるこ とが示された，加えて，本手法は測定に必要な反応 時間が 10 分と短く，マイクロプレートを用いるこ とにより同時に多検体の測定が可能であるため，遥 かに迅速な測定手法と言える。

\section{4. 脂質ラジカル蛍光検出 ·構造解析プローブの} 開発

脂質は，生体膜の重要な構成要素であり，エネル ギー産出やシグナル伝達など様々な生理学的機能を 有する。しかしながら，脂質，特に polyunsaturated fatty acid（PUFA）は極めて酸化を受け易く, ${ }^{14)}$ 脂質由来のフリーラジカル種「脂質ラジカル」を生 じる．本化学種は，脂質過酸化反応を連鎖的に拡大 させ, ${ }^{15)}$ 大規模な生体膜障害及び反応最終産物であ る malondialdehyde や 4-hydroxy-2-nonenal などア ルデヒド種の蓄積を促す. ${ }^{16)}$ 実際に，これらアルデ
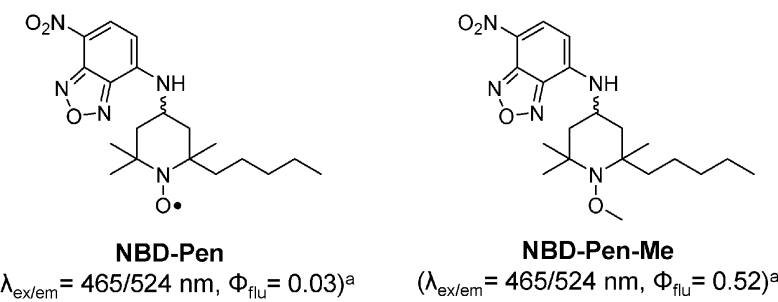

Fig. 6. Chemical Structures and Photochemical Properties of NBD-based Profluorescent Nitroxides Used in This Study aMeasured in $n$-octanol.

ヒド種による機能性分子の酸化修飾は, 全身の様々 な組織における疾患発症に密接に関与する. ${ }^{17,18)} こ$ のため, 脂質ラジカルを検出・解析する技術開発 は，種々の酸化ストレス疾患発症メカニズムの解明 に貢献すると考えられる.

しかしながら，これらラジカル種の多くは高反応 性かつ短寿命なので，通常実験条件下で直接観測す ることは不可能である。一方で，当研究室では近 年，前述のニトロキシド 2,6 位置換修飾合成法を応 用し，脂質ラジカルに高い反応性を有するニトロキ シド誘導体の開発に成功した。 ${ }^{19)}$ そこで，これらを ニトロキシド部位とした脂質ラジカル蛍光ニト ロキシドプローブ 2,2,6-trimethyl-4- (4-nitrobenzo $[1,2,5]$ oxadiazol-7-ylamino)-6-pentylpiperidine-1-oxyl （NBD-Pen）を新たに開発した（Fig. 6). ${ }^{7)}$ 本プロー ブ蛍光原子団部位としては, 脂質ラジカルが生体膜 のように疎水的環境下にて生成することから，環境 応答性蛍光原子団である NBD 基を用いた。また， $\mathrm{N}-\mathrm{O}$ ラジカル部位をメチル化し蛍光消光能を消失 させた NBD-Pen-Me も別途合成した。今回合成し 


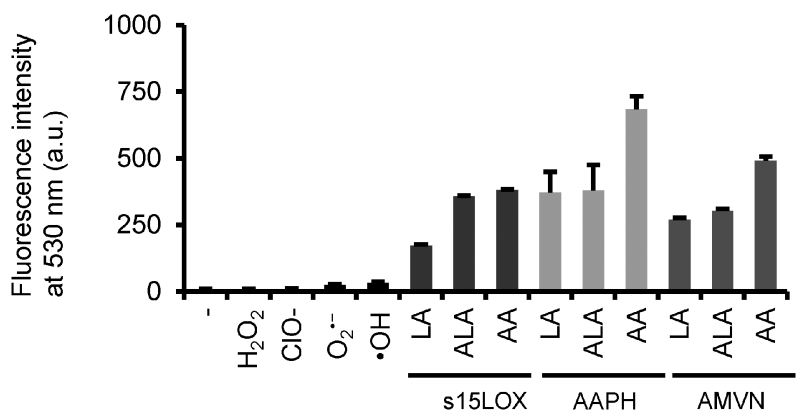

Fig. 7. Fluorescence Response of NBD-Pen to Various ROS and Lipid Radicals

NBD-Pen, $5 \mu \mathrm{M}$ in $0.5 \% \mathrm{CH}_{3} \mathrm{CN} ; \mathrm{H}_{2} \mathrm{O}_{2}, 500 \mu \mathrm{M} \mathrm{H}_{2} \mathrm{O}_{2}$; ClO-, $500 \mu \mathrm{M}$ $\mathrm{NaClO} ; \mathrm{O}_{2}{ }^{-}-, 500 \mu \mathrm{M} \mathrm{KO}_{2}$ in $5 \%$ DMSO; $\bullet$ OH, $500 \mu \mathrm{M} \mathrm{H}_{2} \mathrm{O}_{2}, 5 \mu \mathrm{M} \mathrm{FeSO}_{4}$ - $7 \mathrm{H}_{2} \mathrm{O}$. Lipid: $500 \mu \mathrm{M} \mathrm{LA}$, ALA or AA in $0.5 \%$ ethanol. Lipid/s15LOX: $2.5 \mu \mathrm{g} / \mathrm{mL}$ s15LOX. Lipid/AAPH: $10 \mathrm{mM}$ AAPH. Lipid/MeO-AMVN: 50 $\mu \mathrm{M} \mathrm{MeO}-\mathrm{AMVN}$ in $\mathrm{CH}_{3} \mathrm{CN}$. Solvent: $50 \mu \mathrm{M}$ DTPA in $100 \mathrm{mM}$ PB. FL, fluorescence intensity. $\lambda_{\mathrm{ex} / \mathrm{em}}=470 / 530 \mathrm{~nm}$. Data are mean \pm S.D., and three experiments were performed. Reprinted with permission from Yamada K. I., et al. Nat. Chem. Biol., 12 (8), 608-613 (2016). Copyright $2016 \mathrm{Na}$ ture Publishing Group.
た NBD-Pen 誘導体はいずれも，吸収蛍光極大波長 をそれぞれ $465 \mathrm{~nm}, 524 \mathrm{~nm}$ に有した。 また，各分 子の蛍光量子収率は, ラジカルを消失させた NBDPen-Me では有機溶媒（n-octanol）中において高い 蛍光発光 $\left(\Phi_{\mathrm{NBD}-\mathrm{Pen}-\mathrm{Me}}=0.52\right)$ が観測された一方で, $\mathrm{N}-\mathrm{O}$ ラジカルを有する NBD-Pen では蛍光量子収率 が低下した（ $\Phi_{\mathrm{NBD}-\mathrm{Pen}}=0.03 ）$.

続いて，本プローブの脂質ラジカルに対する反応 性を評価した（Fig. 7)。脂質ラジカルは, 3 種の PUFA (linoleic acid; LA, $\alpha$-linolenic acid; ALA, arachidonic acid; AA) に, 酸化反応開始剤として 大豆由来リポキシゲナーゼ (s15LOX)，2,2'-azobis (2-amidinopropane) dihydrochloride (AAPH), 2,2' azobis (4-methoxy-2,4-dimethylvaleronitrile) (AMVN) の添加により生成させた。結果，NBD-Pen は活性 酸素種に対してはほとんど蛍光応答性を示さず，脂 質ラジカルと混和させた際にのみ発光した。以上よ

\section{a}

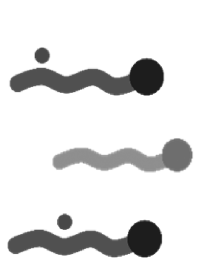

Lipid radicals

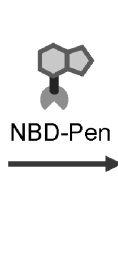

Probe radical adducts
Monitoring (LC/FL)
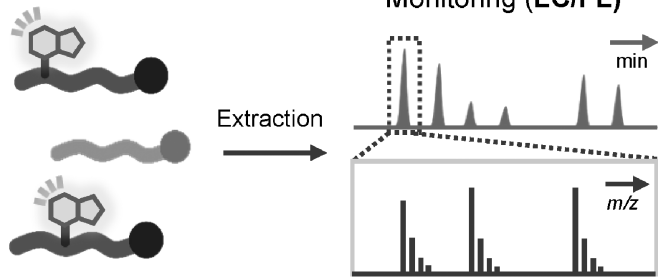

Identification (HRMS/MS)

b

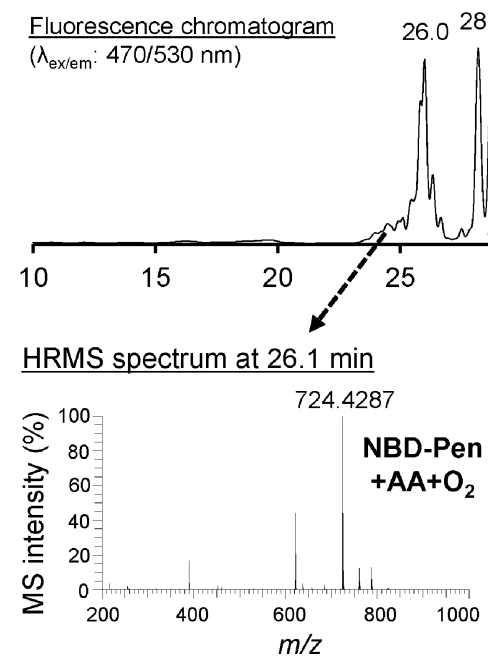

0.2

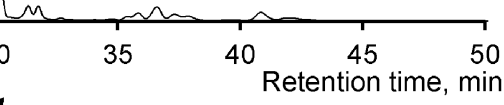

HRMS spectrum at $28.2 \mathrm{~min}$

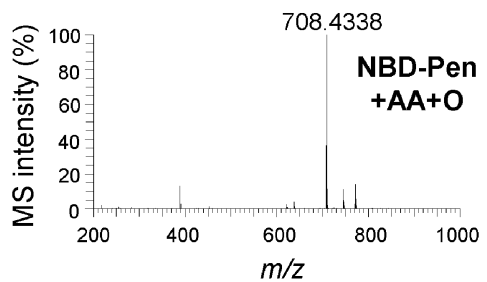

Fig. 8. Structural Analysis of AA-derived Radicals Using NBD-Pen and LC/FL/HRMS/MS System

(a) The combined fluorescence probe and LC/FL/HRMS/MS technique generated MS information at the retention time $\left(t_{R}\right)$ of the enhanced chromatogram fluorescence peak. (b) LC/FL analysis of reaction products between NBD-Pen and AA-derived radicals stimulated by $10 \mu \mathrm{g} / \mathrm{mL}$ s15LOX and HRMS spectra observed at different $t_{\mathrm{R}}$ in total ion chromatogram of s15LOX/AA system. Reprinted with permission from Matsuoka Y., et al. Anal. Chem., 92 (10), 6993-7002 (2020). Copyright 2020 American Chemistry Society. 


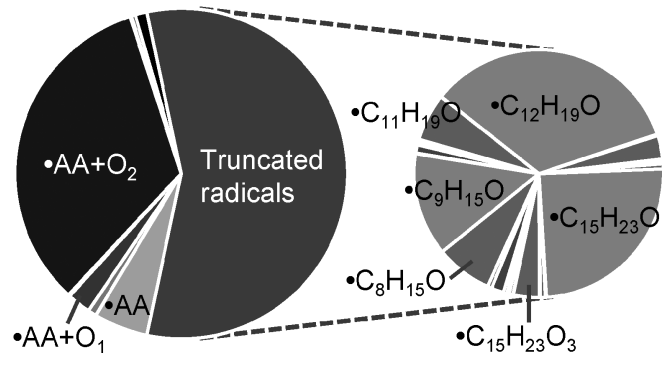

AAPH

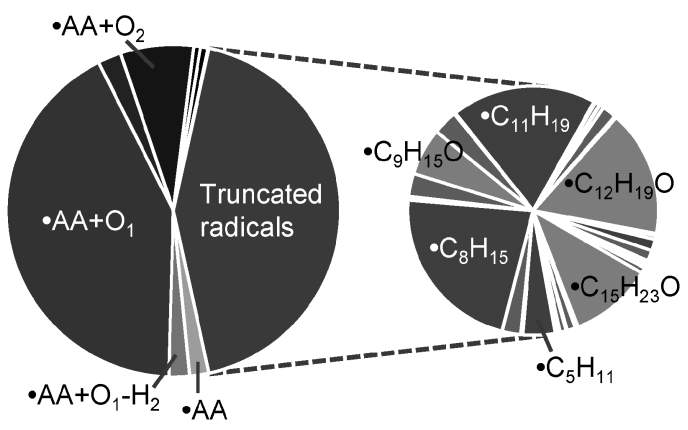

AAPH + Hemin

Fig. 9. Product Profiles of AA-derived Radicals for Each Peroxidation Condition $(50 \mathrm{mM}$ AAPH and $50 \mathrm{mM} \mathrm{AAPH}$ $+10 \mu \mathrm{M}$ hemin)

The relative abundances of each adduct were calculated from each EIC peak area. Reprinted with permission from Matsuoka Y., et al. Anal. Chem., 92 (10), 6993-7002 (2020). Copyright 2020 American Chemistry Society.
り，NBD-Pen は脂質ラジカルを選択的に検出可能 であることが示された。

\section{NBD-Pen を用いた脂質ラジカル構造解析手} 法

NBD-Pen は，脂質ラジカルと反応することで蛍 光性付加体を形成する。 そこで，これら反応後試料 を採取し，結合した蛍光団をマーカーとし LC-FL による分離・付加体の選定，並びに MS による構 造解析を行うことで, 脂質ラジカルの選択的かつ効 率的な構造解析が可能となる [Fig. 8(a) ]. ${ }^{8)}$ Figure 8(b)に， s15LOX 添加により生成させた AA 由来ラ ジカルと NBD-Pen との反応後溶液の LC/FL 解析 結果を示す， S15LOX 添加により脂質ラジカループ ローブ付加体に由来する複数の蛍光ピークが観測さ れた。続いて，各蛍光ピークが観測された保持時間 $\left(\mathrm{t}_{\mathrm{R}}: 26.0\right.$ and $\left.28.2 \mathrm{~min}\right)$ における質量分析結果を確 認したところ，それぞれ NBD-Pen と・AA $+\mathrm{O}_{2}$ (calculated $m / z$ 724.4297), • AA $+\mathrm{O}$ (calculated $m / z$ 708.4341） との付加体に相当する MS ピークが 観測された，以上の結果より，本手法が脂質ラジカ ルの構造解析に応用可能であることが示された.

そこで，本手法を用いて，5種の PUFA（LA，
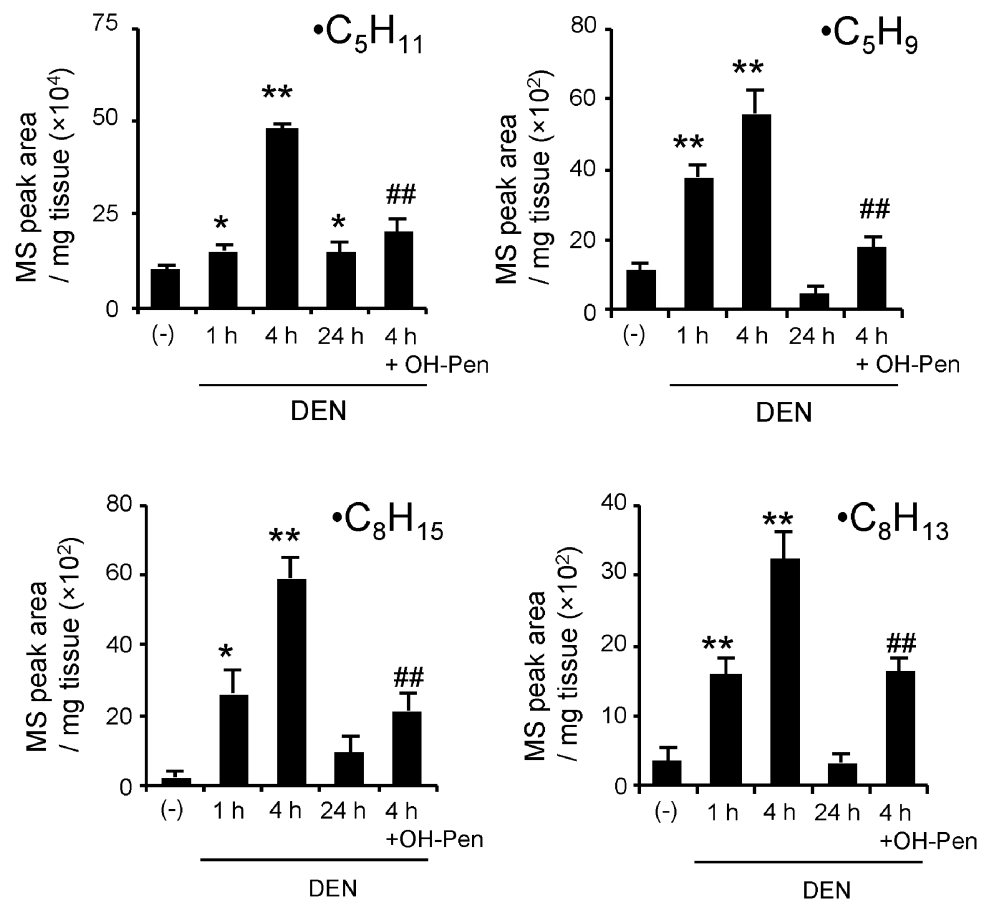

Fig. 10. Semi-quantified MS Peak Areas of Typical Truncated Radicals in Mouse Liver Samples $4 \mathrm{~h}$ after DEN (100 mg/kg in saline) Administration

Mice were administered the lipid-radical scavenger, OH-Pen, 15 min before NBD-Pen injection. Data are mean \pm S.D. of experiments repeated six times. ${ }^{*} p<$ $0.05,{ }^{* *} p<0.005$, as compared to vehicle group. ${ }^{\sharp} p<0.005$, as compared to DEN-treated group after $4 \mathrm{~h}$. Reprinted with permission from Matsuoka Y., et al. Anal. Chem., 92 (10), 6993-7002 (2020). Copyright 2020 American Chemistry Society. 
ALA, AA, eicosapentaenoic acid; EPA and docosahexaenoic acid; DHA）に種々の酸化剂（s15LOX, $\mathrm{AAPH}$, hemin) 添加時に生じる脂質ラジカルの構 造解析を行つたところ，5つの PUFA より生じる 計 132 種類の脂質ラジカル種（うち 111 種類が新規 化合物）の構造推定に成功した。また興味深いこと に，各反応系にて生じる脂質ラジカルの種類・量は 酸化剂の種類に応じて大きく異なることが明らかと なった（Fig. 9)。例として，酸化剂として，非䤉 素的ラジカルイニシエーターである AAPH を用い た際には・ $\mathrm{AA}+\mathrm{O}_{2}$ や hock 開裂による生じるラジ カル種 $\left(・ \mathrm{C}_{9} \mathrm{H}_{15} \mathrm{O}, ・ \mathrm{C}_{12} \mathrm{H}_{19} \mathrm{O}\right.$ and $\left.・ \mathrm{C}_{15} \mathrm{H}_{23} \mathrm{O}\right)$ が 多く生成する. 一方で, 本反応系に鉄ポルフィリン の一種である Hemin を添加すると・AA $+\mathrm{O} や ~ \beta$ 開裂により生じるラジカル種 $\left(・ \mathrm{C}_{5} \mathrm{H}_{11}, ・ \mathrm{C}_{8} \mathrm{H}_{15}\right.$, ・ $\mathrm{C}_{11} \mathrm{H}_{19}$ and $\left.・ \mathrm{C}_{14} \mathrm{H}_{23}\right)$ が多く生成した.

続いて本手法を用い, 疾患モデル動物中において 生成する脂質ラジカルの検出を試みた，疾患モデル として, diethylnitrosamine (DEN) 誘発肝細胞が ん20) 用いた。肝細胞がんは，予後が不良であり， 有効な予防法がない。このため，その疾患発症メカ ニズム解明が望まれている，加えて，現在，肝細胞 がんの発症には酸化ストレスの関与が指摘されてい る. ${ }^{21)}$ そこで，この肝細胞がんモデルの発症時に生 成する脂質ラジカルの解析を進めた。その結果，炎 症初期において生成する計 11 種の脂質ラジカル種 の検出にも成功した（Fig. 10)。なお，これら脂質 ラジカル生成は脂質ラジカル除去剂である 4-hydroxy-2,2,6-trimethyl-6-pentylpiperidine-1-oxyl (OH-Pen) の前処理によって有意に抑制された. 疾患モデル動物において内在性の脂質ラジカルを構 造解析したのは本研究が初めてである.

脂質過酸化反応は近年様々な疾患においてその関 与が示唆されている。 そこで，これら脂質過酸化反 応の起点となるラジカル種の検出は疾患発症のメカ ニズム解明のみならず，新たな治療標的としても大 きく期待できる.

\section{6. 結論}

酸化ストレス疾患は，一般に，過㮃に生成したラ ジカル種により引き起こされ，抗酸化物質の投与 が，その予防・治療法として研究が進められてい る. しかしながら，抗酸化物質の投与による治療は 有効であるとの報告が多数なされている一方で，病
態の改善にまで至らない場合も少なくない。これ は，各疾患において形成される酸化還元バランスを 正しく捉えきれていないことが要因ではないだろう か. そこで本研究にて開発した蛍光ニトロキシドプ ローブを今後, 種々の疾患モデル動物へと応用する ことで，得られた知見を基盤とした新たな疾患診 断・治療法の開発に大きく貢献すると期待する.

謝辞本研究を進めるにあたり，多大なご指 導・ご助言を頂きました, 九州大学大学院薬学研究 院 山田健一教授, 名城大学理工学研究科 福住俊一 特任教授, 大阪大学先導的学際研究機構 大久保 敬教授, 九州大学生体防御医学研究所 馬場健史教 授，和泉自泰准教授にこの場をお借りして御礼申し 上げます。

利益相反＼cjkstart開示すべき利益相反はない.

\section{REFERENCES}

1) Valko M., Leibfritz D., Moncol J., Cronin M. T. D., Mazur M., Telser J., Int. J. Biochem. Cell Biol., 39, 44-84 (2007).

2) Birben E., Sahiner U. M., Sackesen C., Erzurum S., Kalayci O., World Allergy Organ. J., 5, 9-19 (2012).

3) Blough N. V., Simpson D. J., J. Am. Chem. Soc., 110, 1915-1917 (1988).

4) Green S. A., Simpson D. J., Zhou G., Ho P. S., Blough N. V., J. Am. Chem. Soc., 112, 7337-7346 (1990).

5) Sakai K., Yamada K. I., Yamasaki T., Kinoshita Y., Mito F., Utsumi H., Tetrahedron, 66, 2311-2315 (2010).

6) Matsuoka Y., Ohkubo K., Yamasaki T., Yamato M., Ohtabu H., Shirouzu T., Fukuzumi S., Yamada K. I., RSC $A d v$. , 6, 60907-60915 (2016).

7) Yamada K. I., Mito F., Matsuoka Y., Ide S., Shikimachi K., Fujiki A., Kusakabe D., Ishida Y., Enoki M., Tada A., Ariyoshi M., Yamasaki T., Yamato M., Nat. Chem. Biol., 12, 608-613 (2016).

8) Matsuoka Y., Izumi Y., Takahashi M., Bamba T., Yamada K. I., Anal. Chem., 92, 69937002 (2020).

9) Eggersdorfer M., Laudert D., Létinois U., 
McClymont T., Medlock J., Netscher T., Bonrath W., Angew. Chem. Int. Ed. Engl., 51, 12960-12990 (2012).

10) Ma Y., Chapman J., Levine M., Polireddy K., Drisko J., Chen Q., Sci. Transl. Med., 6, 222ra18 (2014).

11) Behrens W. A., Madère R., Anal. Biochem., 165, 102-107 (1987)

12) Yamasaki T., Mito F., Ito $Y$. , Pandian S., Kinoshita Y., Nakano K., Murugesan R., Sakai K., Utsumi H., Yamada K. I., J. Org. Chem., 76, 435-440 (2011).

13) Sun F., Iwaguchi K., Shudo R., Nagaki Y., Tanaka K., Ikeda K., Tokumaru S., Kojo S., Clin. Sci., 96, 185-190 (1999).

14） Pratt D. A., Mills J. H., Porter N. A., J. Am.
Chem. Soc., 125, 5801-5810 (2003).

15) Yin H., Xu L., Porter N. A., Chem. Rev., 111, 5944-5972 (2011).

16) Ayala A., Muñoz M. F., Argüelles S., Oxid. Med. Cell. Longev., 360438 (2014).

17) Stocker R., Keaney J. F. Jr., Physiol. Rev., 84, 1381-1478 (2004).

18) Reed T. T., Free Radic. Biol. Med., 51, 13021319 (2011).

19) Yamasaki T., Ito Y., Mito F., Kitagawa K., Matsuoka Y., Yamato M., Yamada K. I., J. Org. Chem., 76, 4144-4148 (2011).

20) Bartsch H., Hietanen E., Malaveille C., Free Radic. Biol. Med., 7, 637-644 (1989).

21) Wang Z., Li Z., Ye Y., Xie L., Li W., Oxid. Med. Cell. Longev., 7891574 (2016). 